\title{
Osteoid Osteoma of the Sacrum Mimicking Sacroiliitis: A Case Report
}

\author{
Sakroileiti Taklit Eden Sakrumun Osteoid Osteoması: Olgu Sunumu
}

\author{
Gürkan ÖZKOÇ \\ Department of Orthopedics and Traumatology, Başkent University, Adana Teaching and Research Center, Adana, Turkey
}

\begin{abstract}
A 23-year-old female patient admitted with continuous pain localized in her right sacroiliac joint for four months. She had been diagnosed with sacroiliitis in another clinic. Her plain radiographs, bone scintigraphy and laboratory tests were normal. Magnetic resonance imaging showed a nonspecific edema of the bone marrow at the posterior corner of the sacrum which had been misdiagnosed as sacroiliitis. Computed tomography (CT) showed a nidus located posteriorly at the S2 vertebra of the neighboring sacroiliac joint. A removal of the nidus and pathological examination revealed a diagnosis of osteoid osteoma. Although osteoid osteoma is a very rare entity in the differential diagnosis of sacroiliac pain, it should be kept in mind in the presence of aching pain which is refractory to conservative treatment and responsive to nonsteroidal anti-inflammatory drugs. Magnetic resonance imaging is not always diagnostic, whereas CT is more helpful for diagnosing osteoid osteoma.

Key words: Osteoid; osteoma; sacroiliac joint; sacroiliitis.
\end{abstract}

Osteoid osteoma is a small, benign bone tumor that causes significant pain. It is composed of osteoid tissue and is surrounded by a halo of reactive hyperostosis. ${ }^{[1]}$ Osteoid osteoma accounts for about $5 \%$ of all bone tumors and $11 \%$ of benign bone tumors, ${ }^{[2]}$ and it mainly affects adolescents and young adults. ${ }^{[1]}$ This type of tumor predominantly occurs in the appendicular skeleton, but it has been known to appear in the spine in approximately $7-10 \%$ of patients. In these cases, the lesion usually occurs in the posterior elements ${ }^{[3]}$ Osteoid osteoma rarely appears in other parts of the trunk skeleton ${ }^{[1]}$ In the sacrum, the diagnosis is delayed compared with other sites. ${ }^{[2]}$
Yirmi üç yaşında kadın hasta dört aydır sağ sakroiliyak ekleminde süreğen olan ağrı ile kliniğimize başvurdu. Hastaya bir başka klinikte sakroileit tanısı konulmuştu. Hastanın düz grafileri, kemik sintigrafisi ve laboratuvar testleri normaldi. Manyetik rezonans görüntülemede sakrumun arka tarafında kemik iliğindeki özgün olmayan ödem, yanlışlıkla sakroileit olarak tanılanmıştı. Bilgisayarlı tomografide (BT) sakroiliyak ekleme komşu S2 vertebra arkasında yerleşik nidus görüldü. Nidusun çıkarılması ve patolojik incelemesi sonucu, osteoid osteomu tanısı konuldu. Sakroiliyak ağrının tanısında osteoid osteomu çok nadir görülen bir durum olsa da, konservatif tedaviye dirençli ve nonsteroid antiinflamatuvar ilaçlara yanıt veren sızlayıcı ağrı varlığında akla gelmelidir. Manyetik rezonans görüntüleme her zaman tanısal olmamakla birlikte, BT osteoid osteom tanısında daha yardımcıdır.

Anahtar sözcükler: Osteoid; osteom; sakroiliyak eklem; sakroileitis.

\section{CASE REPORT}

A 23-year-old female presented with localized, continuos pain in her right sacroiliac joint that had been occurring for about four months. She had been previously diagnosed with sacroiliitis at another clinic via magnetic resonance imaging (MRI). Her laboratory tests were normal. For a period of time, she had been treated with nonsteroidal anti-inflammatory drugs (NSAIDs). Although these had provided some amount of pain relief, she did not fully recover. The patient refused further treatment at the same clinic and then came to ours. 


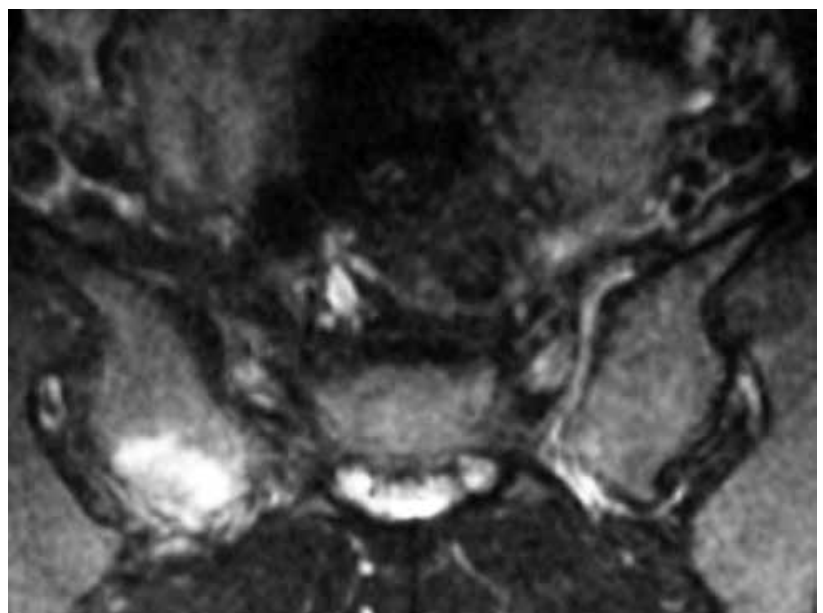

Figure 1. Edema at S3 vertebra.

On physical examination, there was direct sensitivity at her right sacroiliac joint, but there was no swelling. Patrick's test (flexion, abduction, external rotation) was positive on her right side. She was first evaluated with plain radiographs, bone scintigraphy, and laboratory tests. The radiographs were normal, and the bone scan revealed an increased uptake on the right side of the sacrum adjacent to the sacroiliac joint. The tests for erythrocyte sedimentation rate (ESR), C-reactive protein (CRP), leukocyte count, and brucella agglutination were normal. An MRI showed a non-specific edema of the bone marrow at the posterior corner of the sacrum which could have been easily misdiagnosed as sacroiliitis (Figure 1). A computed tomography (CT) scan revealed a nidus located posteriorly at the $\mathrm{S} 2$ vertebra of the neighboring sacroiliac joint (Figure 2).

Surgical resection of the osteoid osteoma through a direct incision located at the sacroiliac joint brought immediate relief of the symptoms, and a pathological

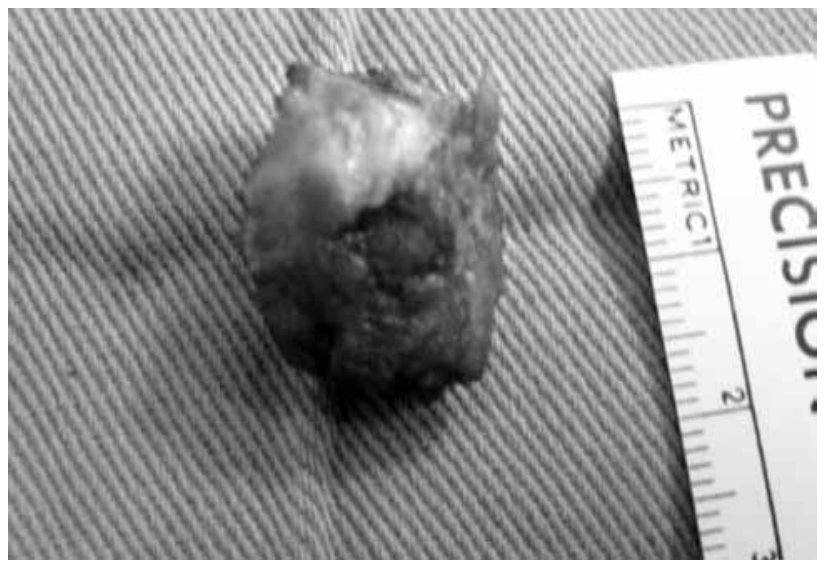

Figure 3. Nidus in the excised bone.

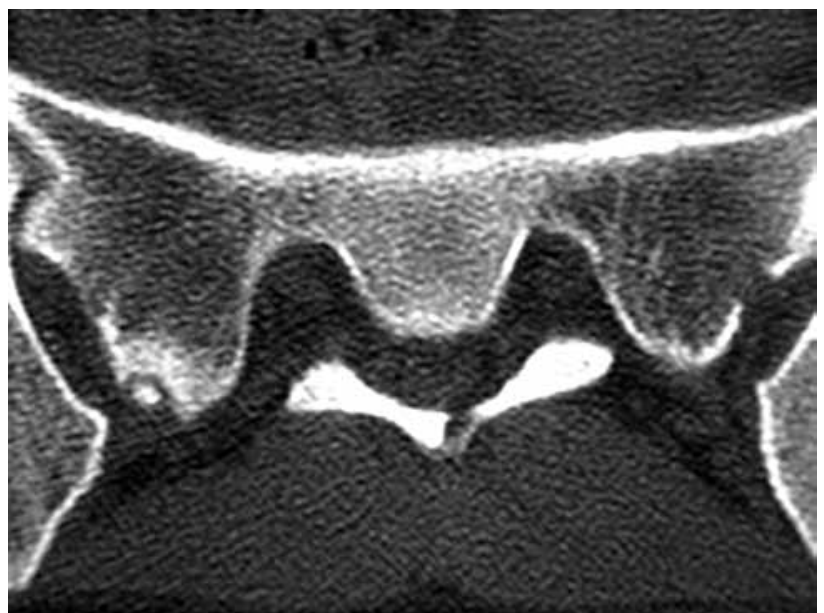

Figure 2. Nidus in the vicinity of the sacroiliac joint.

examination after en bloc surgical excision revealed the diagnosis (Figures 3 and 4).

\section{DISCUSSION}

Involvement of the sacrum is extremely rare, and it has also been reported that the diagnosis of osteoid osteoma in the sacrum can be delayed compared with other skeletal sites. ${ }^{[3,4]}$ Having a history of a dull, aching pain that exists for weeks or months which is worse at night and is relieved by aspirin or NSAIDs is such a common characteristic of osteoid osteoma that it is nearly diagnostic. ${ }^{[5]}$ Curettage through a posterior approach is the treatment of choice. Radiotherapy as well as embolization of the feeding arteries may be used for the most aggressive lesions. ${ }^{[1]}$

In our patient, the diagnosis was delayed and treated as sacroiliitis at the beginning. In the literature, there is only one case report that was misdiagnosed as sacroiliitis, ${ }^{[6]}$ and there was a three-year delay in that diagnosis. In that patient, direct radiography revealed

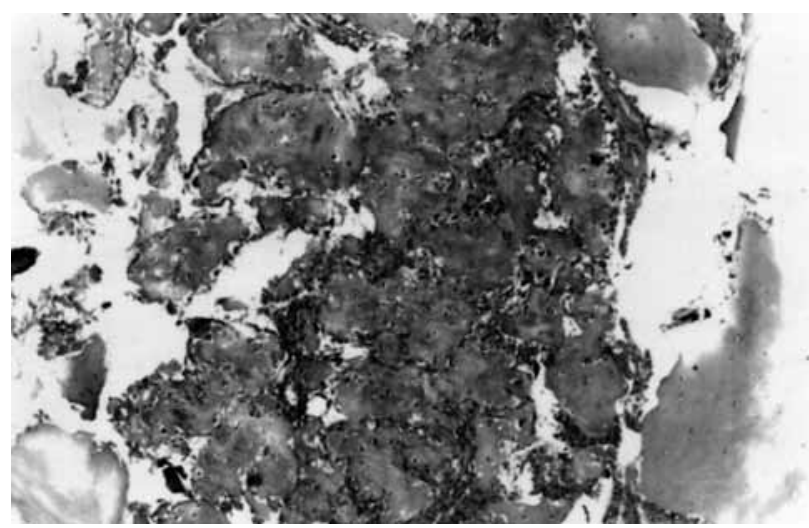

Figure 4. Anastomosing bony trabeculae rimmed by osteoblasts (H-E x 200). 
sclerosis. However, in our case, the onset of complaints had only begun four months previously, and there was no finding on the X-ray. Direct radiography, MRI, and even scintigraphy are not beneficial for diagnosing osteoid osteoma of the sacrum. The nidus is located in the center of the thickening and is always surrounded by the reactive bone sclerosis. Hence, in almost all cases, it is only visible via a CT scan. ${ }^{[5]}$ With our patient, excision through a posterior approach was the treatment of choice. The prognosis for osteoid osteoma is generally good, and there is a low incidence of local recurrence $(<10 \%){ }^{[4]}$

Although osteoid osteoma is a very rare entity in the differential diagnosis of sacroiliac pain, it should be considered in cases that involve an aching pain that is relieved with NSAIDs and in cases involving younger patients when the pain is resistant to conventional treatment. Magnetic resonance imaging is not always diagnostic for osteoid osteoma, but CT has been found to be very helpful in the diagnosis of this type of tumor.

\section{Declaration of conflicting interests}

The authors declared no conflicts of interest with respect to the authorship and/or publication of this article.

\section{Funding}

The authors received no financial support for the research and/or authorship of this article.

\section{REFERENCES}

1. Campanacci M. Osteoid osteoma. In: Bone and soft tissue tumors. New York: Springer-Verlag, Wien; 1999. p. 391414.

2. Schajowicz F. Bone forming tumors. In: Tumors and tumor-like lesions of bones and joints. New York: Springer; 1981. p. 36-47.

3. Marcove RC, Heelan RT, Huvos AG, Healey J, Lindeque BG. Osteoid osteoma. Diagnosis, localization, and treatment. Clin Orthop Relat Res 1991;267:197-201.

4. Biagini R, Orsini U, Demitri S, Bibiloni J, Ruggieri P, Mercuri M, et al. Osteoid osteoma and osteoblastoma of the sacrum. Orthopedics 2001;24:1061-4.

5. Frassica FJ, Waltrip RL, Sponseller PD, Ma LD, McCarthy EF Jr. Clinicopathologic features and treatment of osteoid osteoma and osteoblastoma in children and adolescents. Orthop Clin North Am 1996;27:559-74.

6. Duman I, Aydemir K, Tan AK, Dinçer K, Kalyon TA. An unusual case of osteoid osteoma clinically mimicking sacroiliitis. Clin Rheumatol 2007;26:1158-60. 